\title{
TELEVISÃO - PROBLEMA MÉDICO-SOCIAL DE RELEVVO
}

PROF. NAPOLEÃO L. TEIXEIRA

(Catedrático de Medicina Legal na Faculdade de Direito e ex-Professor Catedrático de Clínica Psiquiátrica na

Faculdade de Medicina da Universidade do Paraná)

\section{I - TELEVISÃO: "MASS MEDIUM" IMPORTANTE}

Por mass medium entenda-se, no moderno conceito norteamericano, fator que exerce influência sôbre as massas. Mass media são, por exemplo, de par com a TV, meios de divulgação como a imprensa escrita, a imprensa falada (rádia) e o cinema.

Se a Imprensa foi chamada o $4 .^{\circ}$ Poder, bem poderíamos dizer que êstes outros fatôres constituem, hoje, sem dúvida, um 5. Poder, tal seu poder de penetração junto ao povo.

Enterreirando o assunto, importa pôr em destaque a televisão, uma das mais notáveis realizações humanas dos últimos tempos. Apresenta-se, portanto, como problema médico-social, vital e educa. tivo, a que nenhum de nós pode ficar alheio.

Nasceu ontem, e segue evoluindo. Do prêto e branco, marcha, a passos céleres, para a televisão em côres: dentro de 10 anos, os atuais receptores terão destino idêntico ao dos antigos gramofones de corda e dos velhos rádios, para ceder lugar a outros que captem imagens em tecnicolor. Isso não baste, e teremos (temos já) a televisão espacial, graças a satélites de comunicação: será ligar o aparelho, no Rio, para captar, diretamente, um programa de Tóquio ou Nova lorque.

Aumenta o número de aparelhos de TV. Cada lar americano tem, pràticamente, o seu: um dos mais conceituados serviços de estatística informou que, sòmente numa semana, 126.564 .000 estadunidenses, maiores de 12 anos, despenderam 2.231.000.000 de horas, a olhar a televisão. O Canadá - um dos países de mais alto grau de saturação no setor da televisão - para uma população de 17.737.400 habitantes, distribuídos em 4.366 .600 residências, apre- 
senta um total de 3.674 .100 residências equipadas com receptores de TV - o que representa $84 \%$ do total. Dados que colhemos em 1960, deram-nos, para a América Latina, um total de 10 milhões de telespectadores, distribuidos por 16 países; havia, em Cuba, 24 estações de TV, 19 no México, 11 na Bolívia e Chile, 99 na Colômbia; figurava o Brasil como o país com maior número de aparelhos receptores (3.910.000), prevendo-se que, naquele ano, a venda dos aludidos aparelhos ultrapassaria a cifra de um milhão.

Honras, pois, à eletrônica que, além dessa maravilha que é o radar, que além do rádio, nos trouxe a televisão - esta conhecida. O rádio, invadindo lares, através do sentido da audição; a televisão fazendo-o através dêste sentido e, o que é mais importante, através do sentido da visão - sabido que "um ôlho vale mais que dois ouvidos" (Loysel) e que, segundo velho adágio chinês, "mais vale uma imagem que um milhão de palavras".

Criar-se-ia terminologia própria: o verbo televisionar; a tele -imprensa, com tele-emissões, tele-jornais, tele-repórteres e tele-notícias; o tele-cinema, o vídeo-tape; o tele-teatro, com tele-romances, tele-autores e atores e tele-novelas, tele-escolas; tele-políticos. De par com tele-virtudes, há, por igual, os tele-vícios. Há, entre os telespectadores, os tele-viciados, não raro vidiotas, quando não tvêsgos. $\mathrm{E}$ nasce a figura do "televizinho"...

\section{II - INFLUÊNCIA DA TELEVISÃO NA FORMAÇÃO CULTURAL DO HOMEM}

Vimos que a televisão irrompe, não só como som, como também como imagem, no lar e na intimidade de cada homem. Daí sua influência incontestável na formação cultural da criatura humana; muito maior que a do cinema e da Imprensa juntos - conclusões a que chegaram estudos feitos na UNESCO.

A influência do cinema - assinala Wlodzimiers Sokorski, presidente do Comitê de rádio e televisão da Polônia - limita-se, particularmente, a películas de argumento e, num sentido, aos noticiários; cuida o rádio de música e notícias políticas, e seus programas são ouvidos de maneira casual, sem que se lhes dispense maior atenção; jornais e revistas são mais assunto de manchetes e de um folhear, sem preocupações maiores com o que nêles vem escrito. Já a televisão obriga a pessoa a ficar num aposento, luz apagada, atenção concentrada no que é obrigado a ver. "When I read a paper", assinala um fã da Tv ianque, "I can simply disagree with the article. When I listen to the radio I can simply turn it off when I feel that I am being forced to accept a viewpoint against my will. This is a 
mechanical habit of cutting oneself off from another individuality. But the television is different. When you speak to me at my home, when I see you, I trust you despite myself. I trust those who come to my home. Otherwise, I would lock my door to them. Please remember that and do not abuse this confidence".

Destaque especial merece, agora, a influência da televisão sôbre o psiquismo da criança e do adolescente. Quando má, em particular. Inexperiente, sugestionável, crédula, imaginativa em demasia, dona de acentuado espírito de imaginação, impressionabilidade fácil, débil seu poder inibitório da vontade a reações motoras irrefletidas - eis algumas das facêtas da psique infantil. Disco virgem sôbre o qual se gravam, com facilidade, impressões boas ou más. Fácil compreender o que poderá "gravar", na cera mole da sua almazinha, essa sub-TV que "grassa" por aí...

\section{III - LADOS POSITIVOS DA TELEVISÃO}

Há, sem dúvida, uma boa televisão, que importa louvar, pondo em destaque alguns dos seus aspectos. Pela rama, dentro dos limites do presente trabalho. Vejamos:

\section{TELEVISÃO E ENSINO}

A televisão educativa (TVE) teve início nos Estados Unidos; as primeiras emissoras regulares começaram em 1948, havendo, atualmente, nesse país, em vários Estados, mais de 500 cursos por ano. As emissões, em circuito fechado, são transmitidas por meio de cabos, e não por ondas. Com finalidade específica, limitada sua utilização ao âmbito universitário, sendo grande o número de universidades dotadas de tais instalações.

Na Grã-Bretanha, realizaram-se as primeiras experiências em 1952. Programas menos numerosos que nos Estados Unidos, concorrem, com vantagem, com as emissões informativas e recreativas. Os programas crescem tanto em dimensão de propósitos, como em têrmos de audiência. O número de escolas que recebem êsses programas alcança já 4.500. Há uma série de transmissões para crianças entre 7 e 9 anos de idade, bem como uma série de aulas de matemática para níveis mais elevados. Há programas destinados a colégios técnicos, tratando de temas relacionados com a engenharia científica; há "programas gerais", um dêles, por exemplo, intitulado "A Nova Europa", destinado a mostrar os efeitos do Conselho Econômico Europeu sôbre a Europa Ocidental. E outros programas, de elevado alcance, que seria fastidioso enumerar.

O Canadá possui, como os Estados Unidos, um sistema descen- 
tralizado de ensino, e seu serviço de TV educativa depende, em grande parte, de uma emissora oficial - a "Canadian Broadcasting Corporation". Seus programas, embora poucos, são de excelente qualidade.

Na França e Itália, a TV educativa é, por igual, de relêvo. Na França, além de cursos diversos, transmitem-se cursos da Sorbonne e peças clássicas da Comédie Française; na Itália, visa, principalmente, a preencher lacunas do ensino secundário, ponto fraco do ensino italiano.

A TVE é também empregada, em larga escala, no Japão, na URSS e na Polônia.

No Brasil, coube a Gilson Amado o mérito de lançar a "Universidade sem Paredes", universidade a serviço do povo, através de uma de nossas estações de televisão. Improvisação altruística, faltando equipe de professôres, instrumentos e material didático, nêsse "mutirão de cultura" (assim o chamou seu idealizador) sobra, entretanto, a mais preciosa das boas vontades. Aulas de Ciência, aulas de História, outras muitas, eis o que promovia, através da TV Continental (Cana! 9), nessa linda Cruzada de Educação e Cultura. Oxalá continue.

Sem o objetivo de fazer crítica ácida - longe de nós tal intenção - lembremos ter havido (não sabemos se ainda há), um curso de alfabetização, pela televisão. Curso elogiado em demasia pela imprensa e publicações ligadas ao ensino, amparado, financeiramente, por diversos patrocinadores, ministrado no período da tarde, em dias da semana, dava ao estrangeiro a falsa noção de que os analfabetos da Paulicéia gozavam de invejável situação: poderiam adquirir aparelhos receptores caríssimos e, o que é importante, poderiam dar-se ao lazer de ficar em casa, em pleno horário de trabalho, a fim de assistirem às tão faladas "aulas de alfabetização".

\section{TELEVISÃO E MEDICINA}

A televisão de circuito fechado é uma das grandes conquistas da última década. Inacessível aos aparelhos domésticos, é transmitida por meio de cabos para projetores e telas de auditórios, teatros, hospitais e salas de aulas.

"Certa noite, assentei-me num auditório, em Nova lorque, com um grupo de 1.800 médicos, diante de uma gigantesca tela de televisão. Víamos, frente a nós, uma clínica de Boston, a 360 quilometros de distância, na qual o especialistas examinavam doentes do coração.

Um dêles ia ser operado. Vimos seus exames de Raios $X$, 
eletrocardiogramas; ouvimos-lhe as batidas do coração; assistimos os especialistas discutindo o diagnóstico e tratamento do caso. Ao ser transportado para a sala de operações, a câmara de televisão o acompanhou. Ouvimos famoso anestesista explicar por que estava sendo aplicado determinado tipo de anestésico, acompanhamo-lo enquanto agia. Terminada a operação a tele-câmara passou para outro cardíaco.

Durante hora e meia, eu e os 1.800 médicos vimos e ouvimos especialistas em ação; simultâneamente, em 49 outras cidades dos Estados Unidos, 18.000 médicos assistiam ao mesmo espetáculo".

A narrativa acima, feita por Don Wharton, dá-nos idéia do elevado alcance da TV, na seara da Medicina. As teleprojeções constituem parte integrante do treinamento dos quartanistas de Medicina da Universidade de Nova lorque.

Os telediagnóstico pode prestar valiosos serviços para socorros à distância. Será possível, graças a êle, guiar a mão de um cirurgião improvisado, a bordo de um navio por exemplo, decidir sôbre a oportunidade de um tratamento imediato ou de transporte para hospital, em casos em que periclite a vida.

A observação médica à distância oferece campo novo, e fascinante, dentro da Medicina Espacial, cujos estudos se fundam, na sua maior parte, na recepção televisiva de imagens que mostram ao observador o comportamento de animais e criaturas humanas, encerrados na cápsula espacial.

Nos Estados Unidos, havia, em 1959, 19 Escolas de Medicina que adotavam a televisão com escopo didático; há, hoje, 40. Intervenções cirúrgicas; no chão da ginecologia, como auxiliar da histerosalpingografia; broncografias; retoscopias, exames do fundus oculi; experimentos de fisiologia em animais - são algumas das muitas possibilidades que a TV oferece à Medicina.

Em erudito e bem documentado trabalho, publicado em 1957, em "Neurology and Psychiatry", Hyman Tucker e colaboradores documentaram algo de nôvo e fascinante, sôbre o efeito psicoterapêutico da TV sôbre doentes mentais. Grupos dos mesmos podem serr tratados, simultâneamente, mediante circuito fechado de TV, numa situação simulada, dando a impressão de tratamento individual. Reduzem-se os sintomas, melhoram as relações sociais. Os pacientes 
reagem favoràvelmente às películas apresentadas na TV, especialmente quando tratam de assuntos relacionados com a Higiene Mental, bem como discussões em grupo, televisionadas. Transmissões sôbre terapêutica artística estimulam os pacientes a participar dêste tipo de atividade; transmissões musicais mostram-se sobremodo úteis em pacientes com indiferença quase total em relação ao mundo exterior. Comparados efeitos, sôbre psicóticas, da TV comercial e da TV em circuito fechado, observou-se que melhoras observadas no primeiro grupo foram de $53,7 \%$, ao passo que as do segundo grupo foram de $63,1 \%$.

\section{TELEVISÃO E TEATRO}

O tele-teatro foi denominado "teatro com milhão de especta dores". Florescem tele-autores, tele-atores, tele-romances, tele-novelas. Há de tudo: do ótimo ao péssimo, passando pelo regular e pelo sofrível. Como no outro teatro, há, neste, o bom teatro, o sub-teatro, o infra-teatro. Destaquem-se, pelo péssimo, novelas chorosas, com abundância de lágrimas e suspiros, os "programas de agonia", tão do agrado dos tele-sofredores, masoquistas que se deleitam e gozam com sofrer. E programas "de terror" - d'epouvante, ao dizer do francês - para um público que tem saudades do mêdo e ama noites povoadas de arrepios e pesadelos.

A maioria das novelas é constituida por histórias falsas, numa ciranda sem fim de situações falsas, vividas por falsos personagens, falando a mais falsa das linguagens, numa atuação que não convence aos poucos que entendem de teatro, mas que impressiona e ilude à massa que os vê e ouve.

E o humorismo então? Noventa por cento do "humor" da TV é humor de cara suja. Exceções raras à parte, que as há, "nosso humor televisivo se estrutura sôbre o lixo, o molambo e o bebum do Páteo dos Milagres" - palavras de Henrique Pongetti que assinala ainda raciocinar, nossa TV, de modo geral em têrmos de chanchada, de quebra-piano, macaquice, burrice muitas e autênticas imbecilidades. Quando seria tão bom e, sobretudo, construtivo, um humor fino, delicado. O que virá, virá ainda, esperamos, temos fé - e ter fé ajuda, sabe-se.

Há, sem dúvida, o bom tele-teatro. Nos países civilizados a mesmo aqui, no Brasil, manda a justiça registrar realizações deste tipo. Não há só criticar - não seria honesto - há louvar, também. Onde louvores cabem, e cabem aqui. Louvores que, estimulando, façam com que o bom se torne mais freqüente. 


\section{TELEVISÃO E RELIGIÃO}

Vimos, há anos, o que foi a bela cruzada de Dom Helder, através da TV, em favor dos flagelados de Orós. Vemos, seguidamente, ministros de tôdas as religiões, através da mesma, levando, aos seus fiéis, uma mensagem de fé e amor - e isso é grande e belo.

Ao concluir uma conferência para um grupo de freiras e professôras, num colégio norte-americano, o Bispo Fulton Scheen pediu Ihe fôssem formuladas perguntas, por escrito. Uma delas: "Poderia V. Exa. Reverendíssima usar da sua influência, junto às Madres Superioras, para que permitam às religiosas assistirem aos programas de V. Exa. Reverendíssima na televisão?" Ao que o Bispo, sob aplausos, respondeu: "Madres Superioras de tôdas as Ordens, por favor, de:xem suas religiosas assistirem aos meus programas"; e acrescentou: "Sou apenas um humilde instrumento; Nosso Senhor entrou em Jerusalém montado num jumento, e Êle bem poderia entrar na televisão em outro..."

Falando sério, que o tema comporta seriedade, sabemos que a transmissão de cerimônias religiosas, a ilustração das verdades da fé, a apresentação de obras-primas da arte religiosa, levam a palavra de Deus a casas, hospitais, prisões e recantos afastados da terra. "Queira Deus venha depressa o dia, em que todos os povos recebam mais fàcilmente o Evangelho, através dêsse admirável instrumento" - palavras de S. Santidade o Papa João XXIII, avaliando, devidamente, o papel da televisão, sua capacidade de transmitir a mensagem animada, vivida, sentida.

\section{OUTROS ASPECTOS DA BOA TELEVISÃO}

Focalizaremos apenas alguns mais. Sem a pretensão de os mostrar a todos, por isso que a cada dia surge nôvo uso para êsse admirável aparêlho eletrônico.

Numerosas firmas industriais usam regularmente a televisão de circuito fechado: mudanças de orientação, técnicas de administração e vendas, são questões entre outras, discutidas e demonstradas, simultâneamente, em lugares distantes um do outro.

Empregam-na bancos, permitindo a pagadores de agências para conferirem, com presteza, fichas dos arquivos da matriz, assinaturas e saldos de depositantes.

Indústrias de fornecimento de força dispõem de câmeras, fiscalizando chamas dos combustores, medidores de água, chaminés. 
Usa-se ainda a televisão, para vigiar crianças em parques infantís, descuidistas em lojas comerciais, freqüentadores de cassinos nas mesas de jôgo, presos em penitenciárias, etc.

\section{IV - LADOS NEGATIVOS DA TELEVISÃO}

Vimos alguns dos lados positivos da televisão. Abordemos, agora, alguns dos aspectos negativos da mesma; alguns apenas, sem a pretensão de os apresentar a todos, o que tornaria demasiado extenso o presente trabalho.

Na opinião de Tristão de Athayde, "a civilização multi-secular da escrita se acha em perigo, ameaçada de desaparecimento, em virtude da ação solapadora dos modernos processos de divulgação, quais sejam o rádio, o cinema e a televisão". Referindo-se a esta última, em palavras recentes, assim se expressou Basil Rathbone, ator consagrado de cinema e teatro e um dos mais destacados intérpretes do repertório shakespeareano: "Filha espúria da arte, que vem deturpando a melhor qualidade de expressão artística que é a pureza".

Há de tudo, em televisão: do bom ao péssimo, do inqualificável ao excelente, quer na parte técnica, quer na parte artística.

A começar pelo linguajar, quantas vêzes condenável, que "grassa" na mesma. Dissemos, atrás, que o humorismo da TV é, não raro, um humorismo "de cara suja", e é exato. Piadas pesadas, têrmos de gíria, linguagem pouco asseada - o que está longe de educativo. Frases assim: "Vem cá, my love, vem abraçar o papaizi nho aqui...", sem contar "humorismo" à custa de bêbados, de loucos, coisas assim.

O excesso de propaganda, cansa pela demasia. Cria vivências novas, na criança. Daí a história da garotinha, televiciada precoce, que, ao chegar o fim da oração do "Pai Nosso", balbuciava, sonolenta, ajoelhada na caminha: "Mamãezinha, será que eu poderia encaixar um textozinho de publicidade sôbre uma bicicleta nova que estou querendo?"

Fôsse apenas excesso, e não seria o mal maior. Acresce, porém, haver verdadeira vigarice no apresentar de muitos produtos no vídeo. Nos Estados Unidos, detetives do Govêrno estão investigando, com resultados surpreendentes, intrujices da televisão comercial: "condimentos aromáticos" em margarina, que não tinham mais "aroma" que o petróleo; "glace" para recobrir bolos, realizada à custa de creme para barbear; "café" cuja aparência soberba é conseguida com vinho quente; panos "muito brancos" e, na realidade, azuis; para. 
brisas de automóvel "que não prejudicam a visão", filmadas sem pára-brisa algum; certo creme de barbear, cuja consistência era demonstrada por um mergulhador que o usava, para se barbear, no fundo do mar, e essa consistência, tão alardeada, era conseguida por ser o mesmo misturado com pasta dentifrícia. São apenas alguns dos muitos exemplos que poderiam ser lembrados.

Alegue-se que a televisão vive do anúncio e que, sem êle, morreria. De acôrdo, mas sem exageros e, sobretudo, com honestidade. Tivéssemos o status alemão, e faríamos o que, na Alemanha, a respeito se faz: havia, nesse país, em 1962, 7 milhões de aparelhos de TV; cada proprietário pagava, ao Govêrno, um impôsto, anual, de 5 marcos por aparêlho; o Govêrno dava, a cada emprêsa de televisão, uma ajuda substancial, de molde a poder oferecer programas ótimos, sem publicidade quase; ficava, esta, reduzida, a 20 minutos por dia, e mesmo assim tinha de ser sàbiamente dosada, de molde a tornar-se pràticamente imperceptivel - e o equivalente a um milhão de cruzeiros.

Falamos, em outro passo dêste ensaio, que a televisão cria verdadeiros tele-viciados. Ah! o desprazer da chegada de uma visita, justamente à hora em que ia começar a novela que se vem acompa nhando, ou justamente no dia do programa predileto: "ah! essas conversas, para que isso, meu Deus!" Vemos, assim, "toxicômanos" de nova espécie, escravos de verdadeira intoxicação auditiva e visual que leva, gradativamente, ao emburrecimento, através de clubes-de-titios, falcões negros, escorpiões, ginkanas, coisas assim. Glosando, diz um americano que, nos States, não há mais famílias numerosas: entre o último programa da noite e o primeiro da manhã, sobra pouco tempo...

Discutíveis os programas do tipo "o céu é o limite" - quitte ou double, na França lascia o radoppia, na Itália, quiz shows, nos Estados Unidos - por várias razões: a primeira, por apresentar. como "muito inteligentes", pessoas dotadas de memória excepcional - sabido que pode haver indivíduos indigentes de inteligência, oligofrênicos mesmo, verdadeiros atletas da memória - sabe-o qualquer psiquiatra; a segunda razão, por dar a verdadeiras desonestidades: caso de Van Doren, nos Estados Unidos, que já sabia o que fingia, face à câmera, esforçar-se para responder; caso ocorrido em Milão, em que uma jovem, nada tola, desmascarou a farsa. Curioso que Van Doren chegou a ser levado às barras da Justiça - absolvido, ora que dúvida! Lindo exemplo!

Se a televisão pode servir para manter a família reunida em casa, pode, às vêzes, ter efeito contrário. Tal o afã de ir correndo 
para assistir aos programas que deixa de existir a boa e santa comunhão à mesa. Passam a viver como estranhos, pais e filhos; aborrecem-se aquêles quando os filhos falam.

Decai, em alguns, o próprio padrão profissional. Aquêle marceneiro, ótimo marceneiro, passa a tornar-se madraço, preguiçoso, desatento, desatencioso: dorme pouco, fica até tarde, vendo televisão.

$\mathrm{Na}$ televisão acham seu paraíso exibicionistas, ávidos de publicidade, sem auto-crítica, que não escolhem meios a fim de aparecer. Por ocasião das campanhas políticas, vêem-se espécimes dessa triste fauna, de arrepiar os cabelos. Falando de política, certo que, aqui e alhures, pode a televisão propiciar debates interessantes: exemplo, - ocorrido nos Estados Unidos, quando de debate assim, entre Kennedy e Nixon - e êsse debate em público muito concorreu, sem dúvida, para a vitória do primeiro.

Há aspectos cômicos, no assunto, como o flagrante original, num processo de divórcio norte-americano: um popular comentarista da TV nova-iorquina desconfiava que a espôsa o traía, durante seus programas, com certo indivíduo; mandou filmar, prèviamente, um dos programas e, enquanto o filme era passado na TV, surgiu em casa, com a Polícia, surpreendendo-os, e não estavam pròpriamente rezando... Embora a espôsa infiel dissesse ao Juíz que a amizade entre os dois era "meramente platônica", o Juíz não concordou e o divórcio foi concedido.

Triste televisão a que se apascenta do sensacionalismo: quando da vitória de Fidel Castro, o fuzilamento de um vencido foi retardado por três horas, a fim de ser televisionado!

\section{TELEVISÃO, EPILEPSIA, SUICÍDIO E DOENÇAS MENTAIS}

a. Televisão e epilepsia - É sabido que diversos tipos de estímulos intelectuais e emotivos, podem desencadear crises convulsivas em indivíduos, especificamente sensíveis - fato conhecido desde Galeno. Nos mercados de escravos da antiga Grécia - conta Apuléio, contemporâneo de Galeno - era comum um espetáculo que tinha algo de misterioso: fazia-se com que os escravos ficassem sentados, com o rosto voltado para o sol, enquanto, diante de seus olhos, se fazia girar, velozmente, uma roda de vaseiro. Alguns acusavam, simplesmente, vertígens e cefaléia, ao passo que outros caíam, tomados de ataque epilético, ou perdiam a consciência. Era uma prova exigida pelos compradores de escravos, teste surpreendentemente moderno e eficaz, para provocar crise convulsiva num epilético latente. Nos últimos anos, o mesmo teste entrou na prática encefalográfica, para 
revelar uma personalidade epilética: o teste é, naturalmente, aplicado com técnica mais precisa. $O$ aparelho usado chama-se estroboscópio e funciona com o mesmo princípio da roda de vaseiro dos antigos gregos: uma fonte luminosa intensa é colocada atráz de um disco perfurado, que roda à velocidade desejada; o ôlho é ferido por uma série de impulsos luminosos, de intensidade controlada, de ritmo calculado. Se, contemporâneamente, se fizer um eletroencefalograma, aparecerão, no gráfico, a certo ponto, os característicos complexos onda-ponta da crise epilética (referência: "TV e Epilepsia", de Dino Collodo, "Rassegna Medica e Cultural", II, 1964, n. ${ }^{\circ} 2$ 2).

Nos últimos tempos, a televisão começa a merecer a atenção dos estudiosos, como possível fator causal das crises convulsivas. TrabaIhos, recentes, de Pallis e Louis e de Mawdlsley, em Lancet (1:188 e 190, ano de 1961), com observações sugestivas. Gastaut e colaboradores (Presse Médicale, 69:1581, 1961) opinam se possa falar numa verdadeira epilepsia pela televisão, apresentando 35 observações de crises observadas em tais condições: $53 \%$, em crianças, de 0 a 10 anos; $18 \%$, entre 11 e 20 anos; $23 \%$, de 21 a 30 anos, e $6 \%$ no grupo etário 31 a 40 anos. Pouparemos pormenores; os interes. sados poderão achá-los no trabalho em referência.

O Digest of Neurology and Psychiatry (novembro, 1962, página 424), revista norte-americana, publicou sugestiva nota a respeito, relativa a trabalho de Pantelekis e Douglas Jones, da Universidade de Birmingham: êstes Autores observaram o que denominam televisioninduced epileps na percentagem de $5,7 \%$ entre crianças epiléticas; apresentam estudo eletroencefalográfico feito em 14 crianças, nas quais as convulsões ocorreram enquanto assistiam a televisão; em 9 dos casos, as convulsões ocorreram sòmente nessa ocasião.

Ao reverso do cinema, cuja ação epileptogênica nunca foi demonstrada, a TV pode desencadear crises convulsivas em individuos particularmente sensíveis. As riscas horizontais oscilantes, verificadas na tela, não estando bem ajustado o aparêlho, e quando se procura pô-lo em sintonia, se mostraram especificamente capazes de gerar o estímulo desencadeador.

b. Televisão e suicídio - É elevado o número de pessoas, suicidas potenciais, suicidas latentes, à espera de estímulo que, agindo como escorva, faça deflagrar a reação autocida. Talvez jamais venham a culminar no autocídio, no propricídio, sem êsse estímulo. O fato é sabido e dispensa comentários.

Pois certos espetáculos televisivos podem atuar sôbre espíritos sugestionáveis, levando-os à autoquíria. Em Londres, em novembro de 1963, Daisy Helen Bracket, de 64 anos de idade, matou-se, atiran. 
do-se a um canal, depois de assistir à retransmissão, pela TV dos funerais do Presidente Kennedy. Após a retransmissão, mostrou-se profundamente angustiada, medicaram-na, mandaram-na dormir; iludiu a vigilança dos seus familiares - eliminou-se. Estávamos em Paris, em setembro de 1959 quando o France Soir noticiou homicídiosuicídio ocorrido na cidade de Lille de casal que, após ver, na TV, o filme Sait-on jamais?, buscou, na morte, a união que a vida the negava: após havê-la matado, matou-se êle, abrindo a torneira do gás, asfixiando-se.

c. Televisão e doenças mentais - "Trinta por cento dos suicídios e das doenças mentais, anualmente registrados nos Estados Unidos, são provocados pela televisão ou pelo cinema" - a afirmativa é da autoria do Dr. Mangalore Narashima, psiquiatra do Hospital Belmont, de Sutton, EUA, em artigo publicado em The Medical Press. Indo além, afirma que a televisão pode causar cefaléias rebeldes, insônia persistente, temor da loucura, a loucura pròpriamente dita, frisando que a insônia é o sintoma predominante em um têrço dos pacientes que se apresentam na seção psiquiátrica do hospital; e diz, textualmente: "uma das causas da insônia é, seguramente, a televisão ou c cinema". Alguns dos pacientes, que me foram confiados para tratamento psiquiátrico, depois de tentarem o suicídio, contaram não haver podido dormir após assistirem a certos filmes ou programas de televisão".

A nós, psiquiatras, que sabemos haver, na etiologia das doenças mentais, não um fator, mas, sim, fatôres, não só uma causa, mas causas, e falemos na poligênia do transtôrno - pecará, por exagerada, a afirmação do colega. Causa desencadeante, sim, mas não causa única. Em todo caso, sem essa causa desencadeante, talvez o mal não viesse a eclodir. Fique, contudo, o registro; à espera de novas contribuições no assunto.

\section{MÁ INFLUÊNCIA DA TELEVISÃO SÔBRE A CRIANÇA}

Há, sem dúvida, bons programas de televisão, para a criança: desenhos animados, filmes aceitáveis, documentários, etc. - são muitos, e não os vamos recordar a todos. Preponderam, porém, os menos maus, quando não são péssimos. Dir-se-á que, aqui ou ali, tais programas são levados em horas em que a criança não os poderá assistir. Tolice: como médico, sabemos de casos e casos de crianças que só vão para a cama, após o último programa. Por negligência dos pais, ou por acreditarem na inocuidade dos mesmos.

Daí notórios prejuízos físicos e psicológicos de que todos temos notícia. Sem contar a influência maninha sôbre a formação do 
caráter e da moral dos pequeninos. Somos de opinião que, dêste ponto de vista, a TV age desfavoràvelmente, não só sôbre a saúde, como também sôbre a cultura, sem contar prejuízos quanto a horas de estudo e no que tange à disciplina doméstica.

Já se assinalou que o abuso da televisão mata a nobre arte de conversar, o alto prazer da leitura, a vida familiar e - por que não? - a própria individualidade. Prejuízo, também aqui, para à criança, que passa a sentir, na família (e será isso família?), um conjunto de pessoas que se detestam.

Diz-se, hoje, que a televisão é o ópio das crianças; passam horas por dia, vendo televisão, preferindo tele-romances aos programas que lhes são destinados, descurando trabalhos escolares e mesmo brinquedos - tudo sacrificando a essa "sêde de imagens". Não endossamos palavras de Peregrino Júnior que, reconhecendo o nenhum valor educativo dêsses programas, "confessa, como avô, que, em certos momentos de tumulto, a televisão é, sem dúvida, D equanil das crianças". Melhor teria sido guardar silêncio, médico que é.

Estatísticas demonstram que, nos Estados Unidos, as crianças, entre 5 e 6 anos, são as maiores aficionadas da TV, a que dedicam de 5 a 6 horas por dia; dos 7 aos 17 anos, a média diária é de 3 horas; para as demais idades, 27 horas semanais - quase o mesmo horário escolar. Mutatis mutandis, digamos que (faltam-nos estatísticas a respeito, no Brasil sempre faltam), guardadas as proporções, entre nós o mesmo se passa.

"A excitação, motivada pela maioria dos programas da televisão, é a causa principal do aumento na frequência e na duração dos maus hábitos noturnos entre as crianças" - observação do pediatra japonês Takao Kimura, professor do Departamento de Medicina da Universidade de Tottori.

Discorrendo a respeito, depõe um médico francês: "Jean-Paul, de 10 anos, era um bom aluno. Por que, no meio do ano escolar, essa falta de atenção na escola, que the valeu passar do 1.0 para o 15.0 lugar? Resposta: seus pais instalaram, em casa, um aparêlho de televisão".

O sisudo "Times", de Londres, estudou o assunto. Várias mães de família, escrevendo à redação, discordaram: não, a TV não afasta a criança dos livros, não diminui seu interêsse pelos livros; e decláraram que agora, mais que nunca, notavam haver aumentado a procura, por parte dos filhos, de dicionários e enciclopédias: para sôbre os mesmos se assentarem e mais comodamente poderem 
assistir aos programas da TV. "Cultura de assento" - humour britânico. . .

Um dos traços da psicologia infantil, é a fácil sugestionabilidade. Acentuado seu espírito de imitação. Fracos seus freios inibitórios. Incompletas, as noções do bem e do mal, do certo e do errado que só vivências e a experiência, mais tarde, lhe trarão. Não é difícıl alcançar o malefício que certas "lições" televisivas Ihe proporcionarão.

O menino Jorge Eduardo, grande fã do programa "Aventuras Submarinas", pôs um saco plástico em volta do pescoço, amarrou-o com um cinto, atirou-se a um riâcho, bradando: "Eu sou o "Homem-rã!" - morreu afogado. Fato ocorrido no Rio, em março de 1963. Quis imitar o heroi do programa. Imitou.

TV: semente de violência: $O$ homem vinha algemado, entre dois policiais. De repente, aproxima-se um indivíduo, saca do revólver, empurra-o contra o estômago do outro, dispara. 10 milhões de pessoas, nos Estados Unidos, viram isso, através do vídeo. Dêsses 10 milhões, alguns milhões eram crianças: acabavam de assistir a um verdadeiro asassinato, o de Lee Oswald.

Violências assim, entrando pelos olhos, aterrorizam a criança; criam-lhe, também, a impressão de ser, êste, o único meio para a solução de conflitos. Diz-se, na França, que "a televisão vale o que valem os pais"; e que valem pais assim, que permitem aos filhos verem coisas dêsse padrão? A resposta é óbvia.

J. Edgar Hoover, diretor do FBI, fêz, há pouco, uma advertência: "O público norte-americano está criando uma atitude de perigosa indulgência para com o crime, a sordidez e a corrupção"; abordando a televisão, disse: "tôdas as noites, ela traz, para nossa sala de estar, sinistros quadros de violência e sadismo".

Pesquisa realizada pela Associação Nacional de Rádio e Televisão, em 1959, nos Estados Unidos, com a duração de uma semana, entre os primeiros programas vespertinos, horário preferido pela criança para assistir a programas de televisão, realizada em sete das maiores estações transmissoras, levantou dados estarrecedores: durante êsse período, nos programas ou filmes transmitidos, verificou ter havido 192 tentativas de assassínio, 161 assassínios, 83 roubos, 60 homicídios justificáveis, 7 atentados de linchamento, 6 explosões provocadas, 2 suicídios, 2 incêndios culposos, 2 casos de tortura. llustrativo, sem dúvida.

Assinala-se que, nos Estados Unidos, exceções à parte, a qualidade dos programas de televisão é a mais baixa possível. Quase 
todos os programas têm, como traço predominante, mortes, sofrimentos, brutalidades. Escrevendo a propósito do observado em sete dias da TV americana, a revista Time registra: esmagaram o crâneo a um homem, quando dormia; uma mulher, amarrada a uma cadeira, foi torturada com uma faca, até morrer; duas atrizes, das que fazem strip-tease foram partidas, em fatias, à navalha; quatro gangsters foram mortos, à bala, na sala de visitas de um cronista; o gerente de um bar foi assassinado, no próprio estabelecimento; um garoto foi morto por um motorista bêbado, que se evadiu. Isso, sem contar dois adolescentes, moídos à pancada; um gravador que levou um tiro na mão e uma mulher, vestindo levíssima camisola, seviciada por mascarados. Finalizando, assinala a referida publicação que o número de pessoas mortas, anualmente, nêsses programas, é superior ao das assassinadas nas seis maiores cidades norte-americanas.

Falando da violência na televisão, assim se expressa John Crosby: "O que sempre me inquietou nos espetáculos de crime, na televisão, não é o fato de que possam levar algum rapaz a imitá-los (embora isso seja, evidentemente, algo que nos deva preocupar), mas a ameaça, que representam, de embotar a sensibilidade aos jovens. Tôda exibição de morte, mostrada na TV, amortece um pouco, a nossa sensibilidade; tôda exibição de tiroteio, abafa os ruídos menores da consciência, apaga os matizes mais delicados do espírito. Isso não tornará as crianças necessàriamente mais sádicas, mas poderá afetar, sèriamente, o seu caráter. $O$ mau exemplo da violência é - repitamos - ser, ela, contagiosa: seu hábito leva a considerar, como pouco importante, a pessoa humana, e como coisa negligenciável a vida".

Estudo feito, por Preston, entre jovens de ambos os sexos, de 6 a 16 anos, a fim de aquilatar suas reações a programas de terror e crime, na TV, concluiu serem nítidas as repercussões sôbre o estado geral, sôbre o sono, apetite e sôbre as condições nervosas de muitos dos observados: 116 das pessoas observadas, apresentavam nervosismo evidente; $85 \%$ das mesmas mostravam distúrbios do sono; as sensações de mêdo aumentaram cinco vêzes, em $94 \%$; $51 \%$, tornaram-se roedoras de unhas. Realçou Preston que êsses programas diminuem o apetite, reduzem o pêso, dão sonos agitados e acarretam dificuldades para as tarefas escolares.

Analisando o decênio que passou, comenta Drew Pearson, relativamente ao que, a propósito, nos States, se passou: "Foi um decênio que presenciou $\circ$ auge da delinqüência juvenil, sem que nada se fizesse para reformar os programas de televisão, que levam - crime e a violência aos lares, durante 8 a 10 horas por dia, apesar 
da indignação das autoridades, ante o "engano" que levou certo professor a receber, com antecedência, resposta a perguntas que Ihe seriam formuladas num programa de $\mathrm{TV}^{\prime \prime}$. Diz, isto, respeito ao famigerado professor Charles Van Doren, a que fizemos referência atrás, de face menineira (boyish), membro de família famosa no mundo das letras, que pactuou numa escroqueria moral sem precedentes, impingida a milhões de telespectadores que vinham "torcendo" angustiadamente, quando do Television Quiz Show de que tomava parte. Levado perante o júri, confessou tudo, sem rebuços. Absolvido? Como não? Absolvido, por igual, pela opinião pública, feito quase heroi...

Exemplificar sempre ajuda: assinalou-se singular concidência, no assassinato do Presidente Kennedy. Dias antes, num filme exibido na televisão, foi focalizado atentado, perpetrado, em iguais condições, durante a presidência Roosevelt, em Miami. Também da janela de um apartamento, igualmente com um fuzil munido de visor telescópico, o assassino alvejou um governador e um prefeito. Talvez a "lição" haja aproveitado a Lee Oswald, na prática do magnicídio...

E entre nós? Manda a justiça reconhecer haver a boa televisão que procura fazer o seu melhor para, divertindo, levantar $\circ$ bom gôsto popular. Há, ao reverso, é pena que assim seja, a má televisão que, através de programas pagos a pêso de ouro, exerce nefasta influência sôbre o espírito dos telespectadores, da criança em particular. Repita-se, aqui, o que foi dito, em relação aos States, no que tange a programas de crimes e terror e suas dolorosas conseqüências sôbre os jovens. Acresça-se que, de par com excelentes programas, há-os, por igual, de baixo nível cultural, quando não altamente condenáveis pelas freqüentes incursões pelo chão movediço da chanchada, pelo mundo mal cheiroso do mau gôsto, quando não pelos pantanais da pornografia.

A TV exerce, hoje, verdadeiro impacto sôbre a juventude. Penetra lar a dentro de milhões de pessoas. Posta, muitas vêzes, a serviço de pessoas sem escrúpulo, que superpõem o dinheiro à moral e que, na sua ganância de lucros cada vez maiores, glorificam a violência, enfeitam a corrupção, pintam os criminosos como heróis, dignos da idolatria da juventude - brado de alarme de J. Edga; Hoover, que fazemos nosso.

\section{PROFILAXIA}

Vimos até aqui estudando lados positivos e negativos da televisão. Dando destaque aos maus aspectos da mesma. Procura. remos, agora, apontar algumas medidas profiláticas. 
Pais e educadores não podem ficar indiferentes ao problemá Necessária se torna uma tomada de consciência da grave realidade e atitudes tendentes a reagir contra a mesma.

O remédio estará em os pais cuidarem de uma verdadeira "dieta televisiva" para os filhos, selecionando os programas, e também nas mãos das estações de TV que deverão dar à criança, "homem de amanhã", programas adequados. Isso não basta, há o recurso da pressão da opinião pública.

Somos contrários a censuras, dêste ou daquele colorido; há, porém, obrigação de insistir para que o mal se corrija.

Falando, em 1957, na Encíclica sôbre o cinema, o rádio e a televisão, O Papa Pio XII assinala as vantagens e perigos dêsses meios de divulgação e entretenimento, menciona, entre outras coisas os perigos que podem apresentar, para as famílias, os espetáculos televisionados, e declara: "A santidade das famílias não pode ser objeto de entendimentos e a Igreja não se cansará nunca, segundo seu pleno direito e seu dever, de empregar tôdas as suas fôrças, a fim de que o santuário não seja profanado, pelo mau uso da televisão. Esta pode contribuir para fortalecer os laços de amor e fidelidade da família, mas sempre sob a condição de que não reduza as virtudes da fidelidade, da pureza e do amor". Lança veemente apêlo aos produtores que não permitam a realização de espetáculos contrários à Fé e à Moral cristãs. Voz que deve ser ouvida.

Manifestamos, certa vez, nossa estranheza a um produtor de televisão, face a alguns dos sub-programas da mesma. Respondeu-nos, dizendo que duas ou três tentativas de levar a efeito coisas sérias tinham sido mal recebidas pelo público, tendo sido bombardeado com azêdas críticas, através das quais ficava patenteado ser o melodrama o gênero preferido. Assim, a TV, como o rádio, refletiria e não criaria o gôsto popular. Êste conceito de "dar ao povo aquilo que o povo deseja", irmão gêmeo do outro "não se pode obrigar o povo a gostar de coisa alguma", resume o que pode haver de mais discutível, para não dizer condenável. O público pode e deve ser educado (ou doutrinado) a apreciar boa música, melhores peças, enfim melhores programas.

Assim, só assim, logrará a televisão, esta maravilha de nossos dias, realizar sua nobre e superior tarefa de ajudar um povo a educar-se, uma nação a engrandecer-se. 